\title{
The Contribution of Digital Marketing to Business Performance: The Case of Companies in the Northern Region of Morocco
}

\author{
Ikram El Hachimi, (PhD Student) \\ National School of Business and Management of Tangier (MASRAG) \\ Abdelmalek Essaadi University, Morocco \\ Imad Ait Lhassan, (PhD Student) \\ National School of Business and Management of Tangier (LAFERAG) \\ Abdelmalek Essaadi University, Morocco \\ Mahmoud Belamhitou, (Professor) \\ National School of Business and Management of Tangier (MASRAG) \\ Abdelmalek Essaadi University, Morocco
}

Doi:10.19044/esj.2021.v17n8p82

Submitted: 29 January 2021

Accepted: 26 February 2021

Published: 31 March 2021
Copyright 2021 Author(s)

Under Creative Commons BY-NC-ND

4.0 OPEN ACCESS

Cite As:

El Hachimi. I., Ait Lhassan, I., \& Belamhitou, M. (2021). The Contribution of Digital Marketing to Business Performance: The Case of Companies in the Northern Region of $\begin{array}{lllll}\text { Morocco. European } & \text { Scientific Journal, } & \text { ESJ, } & 17(8), & \end{array}$ https://doi.org/10.19044/esj.2021.v17n8p82

Abstract

Digital marketing is revolutionizing the organizational structures and offers companies, especially Moroccan companies, a multitude of opportunities to evolve the classic business model to innovate in products and services while building a direct and personalized relationship with customers. Indeed, digital marketing highlights important features for companies seeking efficiency and performance, and it considers an attractive alternative to traditional approaches as a response to the challenges of globalization. The ultimate objective of our research is to confirm the direct relationship between digital marketing and the business performance of companies in the northern region of Morocco. The result of the study was noted by many authors. On this matter, we have conducted a quantitative 
survey carried out among 120 companies in the northern region of Morocco using the PLS path modeling, a method particularly suited for academic development and predictive applications. According to our empirical study, we found that digital marketing has a positive impact on the performance of companies in the northern region of Morocco.

Keywords: Digital Marketing, Business Performance, Top Management Support, Digitalization, Technology 


\section{Introduction}

The business world and the functioning of markets are progressively digitalized, which is upsetting the development strategies of organizations and the rules of competition. Digitalization also extends to the services and products offered by companies, and it also changes the relationship between suppliers and customers.

Digitalization offers companies the agility and flexibility they need to optimize their production and respond effectively to the demands of customers who, in turn, have become informed and connected. It also enables them to adapt quickly to market fluctuations and to preserve and/or acquire their competitive position.

Digitalization now affects all functions of the company. Consequently, the marketing and sales department is not an exception. Therefore, the advent of digital marketing, which in turn allows optimizing the actions deployed by companies, deliver the right information and offer the right products at the right time.

Nowadays, digital marketing offers many opportunities for all types of companies that want to tackle the risks of competition. Digital marketing is seen as a constantly evolving device and provides effective and tailormade answers to new consumer's requirements. In addition, optimizing efficiency and performance is one of the major challenges that companies must face by seizing all the advantages offered by digital marketing.

Performance is a pervasive notion in the existence of a company and its improvement is one of the concerns that every company strives to address in order to ensure a better allocation of resources and achieve satisfactory results. Thus, digital marketing through the implementation of marketing and commercial actions can be considered as an excellent opportunity to generate more profits and therefore promote the company's performance.

This paper focuses on shedding light on the contribution of digital marketing to business performance. It is essentially based on the fact of apprehending through a conceptual model, an exploratory factorial analysis, and a confirmatory factorial analysis via the method of structural equations in order to study the impact of digital marketing on the business performance of companies, particularly in the northern region of morocco.

In other words, the ultimate objective of our paper is to answer our main question, which will be stated as follows: Does digital marketing contribute to the business performance of companies in the northern region of Morocco?

In order to answer our main question, we will opt for a research methodology based on a literature review to identify, on the one hand, the concept of digital marketing and, on the other hand, that of performance. In addition, we will also highlight the theoretical contribution of the 
relationship between digital marketing and business performance. Similarly, we will complete our documentary and theoretical research by a quantitative study with a sample of 120 companies in the northern region of Morocco and this through a survey based on the administration of a questionnaire.

\section{Theoretical Background}

Today, Moroccan companies in all sectors are affected by what is called digital transformation. These include new digital uses undertaken by companies to improve their performance through new technologies, both functionally and commercially. Similarly, the Moroccan market is very competitive; in order to stand out, communication and marketing are key positions. Consequently, the top management of each company must be aware of the challenges and opportunities that digital technology offers for the development of their activities and the improvement of their performance, especially business.

We will, therefore, through this point, expose the conceptual and theoretical framework of our article by presenting the basic concepts (digital marketing, business performance, top management support).

\section{Digital Marketing: An Art with a Meteoric Rise}

Laurent Flores (2012) in his book "Measuring the effectiveness of digital marketing" has defined the term as follows:

"Digital marketing brings together all the interactive digital tools to promote products and services in the context of personalized and direct relations with consumers. It concerns all digital contact points: Internet, Smartphones, tablets... Its development is driven by changing uses: multiscreen and multi-tasking; media consumption is also multiplying".

Definitions-Marketing.com defines digital marketing as follows:

"Digital marketing refers to all marketing techniques used on digital media and channels. The term is probably destined to disappear, as marketing tends to become "inherently digital". Digital marketing essentially covers marketing applications related to the "traditional" Internet, but also those related to cell phones, tablets, GPS and other connected applications and objects. Mobile marketing (mobile sites + mobile applications) is becoming more and more important.'

Bressolles et al. (2016), in his book titled "Le marketing digital", gave us the following definition:

"Digital marketing can be defined as the process of planning and implementing the development, pricing, communication, and distribution of an idea, product, or service to create exchanges, in whole or in part using digital technologies, that are inconsistent with individual and organizational objectives. The implementation of digital marketing techniques is aimed at 
acquiring new customers or improving the management of the relationship with existing customers. Digital marketing is of course integrated with traditional marketing tools in a multi-channel/cross-channel marketing strategy."

We can therefore deduce that digital marketing is all the marketing activities of an organization carried out via digital channels (website, e-mail, social networks, mobile, connected TV ...).

The digital shift that Morocco is experiencing generates an astronomical amount of data that companies will have to exploit to better know their customers and deliver an appreciated advertising message. However, the sales function is at the heart of this essential ability to support and better anticipate changes. Indeed, its unique position within the organization leads it to manage the changes of a customer which is always more connected, more attentive and more demanding, as well as the expectations of teams for more recognition and perception.

\section{Business Performance: What Does it Mean?}

Performance is a concept commonly evoked both in daily life and in professional life. It has become an obligation for the different actors irrespective of their field of action. Its improvement has become a challenge for any company concerned about its survival and its brand image in the market in which it operates.

Before focusing on the notion of business performance, it is a good idea to first define the concept "Performance".

Etymologically, the word "performance" entered French dictionaries in 1839. It is borrowed from the English word "performance", derived from "to perform" (to realize, to accomplish) which itself comes from the old French performer.

Literally, Waldman (1994) defines performance as "the set of actions that enable the coordination and improvement of the activities and results of an organizational unit". Khemakhem defines it as "the performance of work, the way in which an entity reacts to incentives or achieves the objectives set for it". Marchersney (1991) equates it with the degree to which the goal is achieved.

While corporate performance is relevant to all functions, we will focus on business performance since it is the basic element of our study.

Business performance can be translated into the achievement of business objectives in a way that is relative to the means used to achieve them. It is defined by Ouattara (2007) as "the ability of the firm to satisfy its customers by offering them goods and services of good quality that meet their expectations. Plauchu and Taïrou (2008) define it as: "the art of being present at the right interlocutor at the right time, with a relevant offer, which 
allows the establishment of long-lasting and profitable business relationships for the company in a context of permanent search for excellence of the service".

In addition, there are many levers for improving the company's business performance, as follows:

-Knowing and understanding your market

It is a matter of knowing and understanding the factors that influence the company's results, and above all, knowing how to use this knowledge to produce more value in the future.

\section{-Differentiate yourself from the competition}

To apply a differentiation strategy to attract more customers and to retain them, which will allow the company to be more attractive and do more business.

\section{-Evaluate its business activity}

Measurement is the essential fuel for the proper functioning of any business system. The company must know how to measure the effectiveness of the business activity and monitor all the key aspects of its business performance by evaluating customer assets and measuring the business performance action.

\section{- Direct the business action}

The sales policy is the operational translation of the company's strategy, for example: Setting the company's sales objectives or identifying targets to approach or develop.

\section{-Setting individual contribution}

The management system is everything that contributes to defining, motivating, monitoring, and evaluating the individual work of sales people. It is the driving force of the business activity.

\section{-Managing your sales force}

The managerial practice is measured by the ability of the manager to use all sources of power at his disposal to manage his team. He must learn how to articulate and encourage them in order to increase his power of influence over his team and focus energies on the company's priorities.

Indeed, the company's business performance becomes an indispensable notion insofar as it allows it to know its notoriety, its place within the market, its positioning, the different products that customers have appreciated, etc.

The business performance also allows the different actors of the company to know the main levers of their performance and customer satisfaction. This is very important since the objectives of any company are to attract as many customers as possible and to make the best possible sale.

Since digital marketing is revolutionizing all sectors of activity and affects the majority of consumers, company managers must mobilize the 
technical, human, and financial resources to take advantage of this undeniable phenomenon for the sustainability of the company.

\section{Top Management Support: Role and Definitions}

In this work, Mahoney (2011) considers top management support as a series of behaviors adopted by the most senior managers of companies, with a view of the success of technological projects. We retain his definition of management support as "the extent to which a senior manager is personally committed through specific behaviors to promote the success of an information technology project".

Mahoney (2011) defines the latter as a belief reflecting the result of a series of behaviors of a top manager, who communicates his beliefs to others in the organization.

Many organizational and environmental factors influence a company's commitment to innovation. Among the organizational factors, the perception of the management team and the team dynamics are expected to have a significant direct impact on the company's commitment to innovation (Daellenbach et al., 2002).

Thus, understanding new uses of digital technologies is not exclusive to IT departments, as business leaders need to understand more about digital trends, their impacts, and how to take advantage of them (Harvard Business Review, 2015). This refers not just to knowing how technology works, but also to understanding its importance and how to use it. Thanks to the power of technology, which requires new skills in $\mathrm{R} \& \mathrm{D}$, marketing, and customer relations. Also, leading digital companies have developed new markets and have increased their margins compared to their competitors. According to the Harvard Business Review report (2015), this goes through the top, where CEOs must absolutely define and communicate a digital vision and strategy, and place new skills across all functions of their companies because any lack of digital leadership could be an obstacle to their development.

Similarly, companies that are beginning a process of digital transformation cite a variety of reasons (Dudézert, 2018). Firstly, an evolution in the source of value creation and customer expectations, leading companies to evolve their product and service offering, thanks to new digital practices. Next is the role of employees, who tend to be in collaborative mode with the company, in creating greater autonomy and capacity for action. Last motivation refers to the need to reduce costs, even if the investments in terms of setting up digital platforms are quite significant.

With regard to all these issues, the digital transformation, compared to other transversal approaches, is encouraged with the support of the general management, the executive committee of the organization or the director of human resources (Dudézert, 2018). According to the author, this support is 
translated, in addition to the computer equipment to the employee, by the allocation of time dedicated to specific training, seminars, and the creation of new jobs (chief digital officer) or departments dedicated to digital projects.

Ultimately, digital technologies are rapidly changing the environment in which companies operate, changing the rules of competition, affecting the structure of the industry, and providing companies with new ways to outperform their competitors.

\section{Literature Review}

The digital revolution offers opportunities that have revolutionized the way companies market themselves (Simpson, 2007), resulting in changes in the nature of trade and the way companies and consumers relate to each other.

Indeed, all players agree that the digital transformation is shifting value within sectors, whether they are industrial or service sectors, whether companies operate with industrial clients or in the general public sector (Besson, 2016, p. 8). The digital transformation, by promoting connectivity and the use of digital tools by companies, is permanently changing the way they operate (Deloitte, 2016) and the relationship with their clients. It develops creativity and innovation and increases their impact on customer satisfaction and loyalty (Kenmogne et al., 2018), which has a positive impact on their business performance.

Digital marketing allows for a better understanding of the customer experience by offering personalized services across multiple touch points (video, sms, social media, website, smartphone...). According to Day (2013), many executives say that digital marketing investments are the most important because it reshapes the relationship between the company and its customers, and it allows them to gain competitive advantages, even if its impact differs from one industry to another.

Digital marketing increases the effectiveness and efficiency of traditional marketing, bringing out new business models that will deliver more value to customers and increase company profitability (Strauss \& Frost, 2014). Thus, this confirms the findings of many researchers such as Brodie et al. (2007) and Trainor et al. (2011).

Moreover, Adam et al. (2009) spoke about the distinction between the two marketing practices, which are digital marketing and traditional marketing, with an effect of the latter only on financial performance, while digital marketing has a positive effect on both business and marketing performance.

On the other hand, we point out that Brentani and Kleinschmidt (2004) found that certain dimensions that define the behavioral environment of the company, namely organizational culture and the commitment of the 
company's management, have a direct link with the performance of new innovative products. This commitment of the management is defined by them as the degree, positive or proactive attitudes, to which the management supports the process of developing new products by allocating the necessary resources and capital.

Understanding the impact of the implementation of digital marketing within Moroccan companies on their business performance is our main objective. Thus, we wish to empirically verify the impact of the top management support and the digital marketing use on the business performance in the Moroccan market more particularly in the northern region. Consequently, our conceptual model a priori is presented as follows:

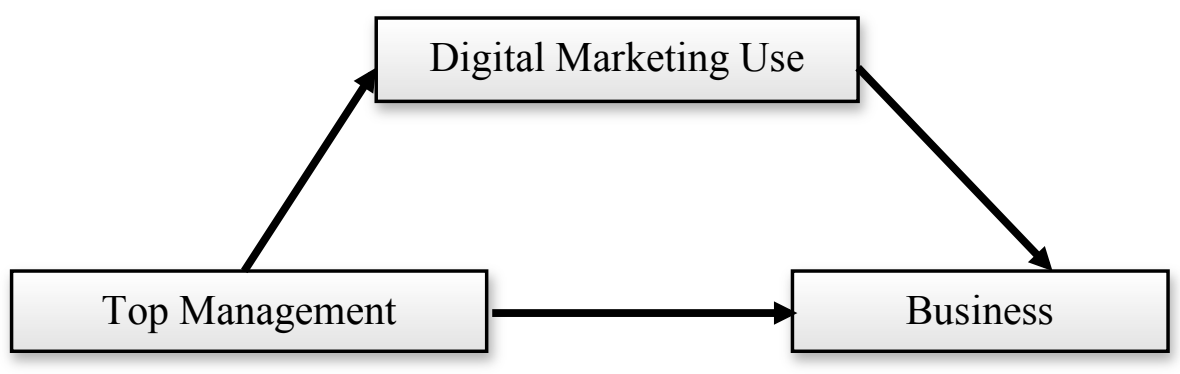

Figure 1. Conceptual model

\section{Methodology}

This research is set up from empirical research with directors and sales managers and other executives within companies in the northern region of Morocco, respecting the steps of the Churchill paradigm.

The figure below shows the different phases of the Churchill paradigm approach:

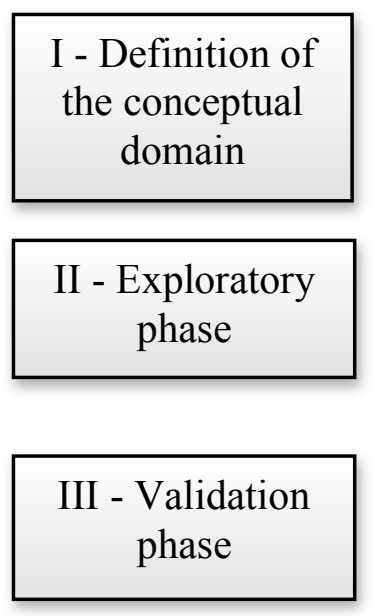

\begin{tabular}{|c|}
\hline 1 - Specify the domain of the construct \\
\hline 2 - Generate a sample of items \\
\hline 3 - Collect data \\
\hline 5 - Collect data \\
\hline 6 - Estimate reliability \\
\hline 7 - Estimate validity \\
\hline
\end{tabular}

Figure 2. Research methodology according to Churchill (1979) 
Our paper aims to carry out two empirical phases in order to study the impact of digital marketing on the business performance of companies in the northern region of Morocco:

The Quantitative Exploratory Phase: It is conducted by a survey administered by a questionnaire. Data are collected from a sample of 120 companies in the northern region of Morocco which are subject to purification through exploratory factorial analysis methods including Principal Component Analysis (PCA). Also, the result of this purification will be presented. Note that this step is necessary to assess the psychometric quality of the scales used to collect the data and is a fundamental prerequisite for applying the regression method. These analysis were performed using SPSS 25 software.

The Quantitative Confirmatory Phase: A final step is the validation of the hypotheses using the SMART PLS 3 software using both simple and multiple linear regression methods. As a result of the hypothesis testing presentation, the discussion of the results will be addressed.

The questionnaire was tested on a sample of 30 respondents to ensure that they fully understand the questions and are not likely to refuse to answer. The final version of the questionnaire, measuring all items (19 items) on a five-point (Likert) scale, was administered to 281 target respondents. 126 were returned completed for an initial response rate of $44.84 \%$. Of these 126 responses, six (6) responses were unusable due to missing data, and therefore the actual response rate is $42.70 \%$. Ultimately, data from 120 companies in the northern region of Morocco could be processed.

Table 1. List of variables and number of research items

\begin{tabular}{|c|c|l|}
\hline Variables & Items & \multicolumn{1}{c|}{ Authors } \\
\hline Marketing Digital Use & 9 & $\begin{array}{l}\text { (Brodie et al., 2007) } \\
\text { (Sheikh et al., 2018) }\end{array}$ \\
\hline Top Management Support & 4 & $\begin{array}{l}\text { (Brodie et al., 2007) } \\
\text { (Chavey, 2010) } \\
\text { (Morgan, 2012) } \\
\text { (Trainor et al., 2011) }\end{array}$ \\
\hline Business Performance & 6 & $\begin{array}{l}\text { (Germann et al., 2013) (Sheikh } \\
\text { et al., 2018) }\end{array}$ \\
\hline
\end{tabular}

With regard to the characteristics of the companies in our sample, we focus more specifically on the legal status, size, and business lines of companies in the northern region of Morocco. 
Table 2. Companies' profile

\begin{tabular}{|c|c|c|}
\hline $\begin{array}{c}\text { Companies' } \\
\text { characteristics }\end{array}$ & Frequency & Percentage \\
\hline \begin{tabular}{ll} 
& \multicolumn{1}{c}{ Legal status } \\
- & SA \\
- & SARL \\
- & SNC \\
- & Others \\
\end{tabular} & $\begin{array}{c}25 \\
89 \\
2 \\
4\end{array}$ & $\begin{array}{c}21 \% \\
74 \% \\
2 \% \\
3 \% \\
\end{array}$ \\
\hline \begin{tabular}{ll} 
& \multicolumn{1}{c}{ Workforce } \\
- & Less than 10 \\
- & Between 10 and 100 \\
- & Between 100 and 250 \\
- & More than 250
\end{tabular} & $\begin{array}{l}12 \\
18 \\
60 \\
30\end{array}$ & $\begin{array}{l}10 \% \\
15 \% \\
50 \% \\
25 \% \\
\end{array}$ \\
\hline $\begin{array}{ll} & \text { Activity area } \\
\text { - } & \text { Services } \\
\text { - } & \text { Manufacturing } \\
\text { - } & \text { Construction } \\
\text { - } & \text { Trade } \\
\text { - } & \text { Others } \\
\end{array}$ & $\begin{array}{c}24 \\
77 \\
3 \\
10 \\
6\end{array}$ & $\begin{array}{c}20 \% \\
64 \% \\
3 \% \\
8 \% \\
5 \%\end{array}$ \\
\hline
\end{tabular}

Based on the information collected, we distinguish within our sample divided into 89 companies with the legal status of "limited liability company", 25 companies with the legal status of "public limited company", 2 companies with the legal status of "general partnership", and 4 other types of companies such as family and associative that use digital marketing.

The second part of the table reveals that $25 \%$ of companies in the northern region of Morocco correspond to large companies with more than 250 employees. Small and medium enterprises represent $50 \%$ of the sample against $25 \%$ for very small companies.

In the third part of the table on the distribution of firms by activity, we found that $64 \%$ of firms located in the northern region of Morocco refer to industrial firms, $20 \%$ to service firms, $8 \%$ of firms carry out trade, and $4 \%$ of firms specialize in construction.

As part of the characteristics of the respondents interviewed, we describe the positions held and their experiences. 
Table 3. Respondent's profile

\begin{tabular}{|c|c|c|}
\hline $\begin{array}{c}\text { Respondent's } \\
\text { characteristics }\end{array}$ & Frequency & Percentage \\
\hline \begin{tabular}{ll} 
& \multicolumn{1}{c}{ Position } \\
- & Marketing manager \\
- & Business manager \\
- & General manager \\
Others
\end{tabular} & $\begin{array}{c}57 \\
36 \\
9 \\
12\end{array}$ & $\begin{array}{c}47,5 \% \\
30 \% \\
7,5 \% \\
10 \%\end{array}$ \\
\hline \begin{tabular}{ll} 
& \multicolumn{1}{c}{ Seniority } \\
- & $0-1$ year \\
- & $2-5$ years \\
- & $6-10$ years \\
- & 11 years and over
\end{tabular} & $\begin{array}{l}10 \\
74 \\
20 \\
16\end{array}$ & $\begin{array}{c}8 \% \\
62 \% \\
17 \% \\
13 \%\end{array}$ \\
\hline
\end{tabular}

A reading of the second table of the distribution of respondents working in companies in the northern region of Morocco indicates that $37 \%$ of respondents are marketing managers, $30 \%$ are sales managers, $10 \%$ are executives, and $8 \%$ are general managers.

Marketing and sales managers are the people who practice digital marketing to improve the business performance of their companies.

We note from the second part of the table that $62 \%$ of respondents working in companies in the northern region of Morocco have between 2 and 5 years of experience, $17 \%$ have an experience of 6 to 10 years, and finally $13 \%$ of respondents have an experience of more than 11 years.

\section{Data Analysis and Results}

In this section, we present the results and analysis of our empirical study, which involves two important steps, exploratory factor analysis and confirmatory factor analysis.

Regarding the empirical study, we refer to a sample of 120 firms in the northern region of Morocco, subjected to a few steps in a first stage. Thus, the exploratory factorial analysis was carried out using SPSS 25 software for the purpose of purifying the items of our research model.

In the second step, the confirmatory factorial analysis carried out using the structural equations method and SMART PLS 3 software leads us to test the hypotheses of our study, and to validate our research model.

\section{Exploratory Factor Analysis}

This section presents the analysis of the results of our empirical study, which includes the two explanatory variables (Use of digital marketing and 
Top Management Support) and the variable to be explained (Business Performance).

We began with an exploratory factorial analysis in our empirical study using SPSS 25 software, which allowed us to perform a purification on the items of each variable studied.

Table 4. Results purification of the scale of measurement of the variable "Digital Marketing Use"

\begin{tabular}{|c|c|c|c|c|c|}
\hline \multirow{2}{*}{ Variable } & \multirow{2}{*}{$\begin{array}{l}\text { List of } \\
\text { items }\end{array}$} & \multirow{2}{*}{$\begin{array}{l}\text { Number } \\
\text { of items }\end{array}$} & \multirow{2}{*}{$\begin{array}{c}\text { Quality of } \\
\text { representation }\end{array}$} & $\begin{array}{c}\text { Factor } \\
\text { contribution }\end{array}$ & \multirow{2}{*}{ Reliability } \\
\hline & & & & $\begin{array}{c}\text { Component } \\
1\end{array}$ & \\
\hline \multirow{9}{*}{$\begin{array}{c}\text { Digital } \\
\text { Marketing } \\
\text { Use }\end{array}$} & UDM1 & \multirow{9}{*}{9} & 0,648 & $\mathbf{0 , 8 0 5}$ & \multirow{9}{*}{0,934} \\
\hline & UDM2 & & 0,705 & $\mathbf{0 , 8 4 0}$ & \\
\hline & UDM3 & & 0,611 & 0,782 & \\
\hline & UDM4 & & 0,689 & $\mathbf{0 , 8 3 0}$ & \\
\hline & UDM5 & & 0,618 & 0,786 & \\
\hline & UDM6 & & 0,599 & 0,774 & \\
\hline & UDM7 & & 0,622 & 0,789 & \\
\hline & UDM8 & & 0,677 & $\mathbf{0 , 8 2 3}$ & \\
\hline & UDM9 & & 0,736 & $\mathbf{0 , 8 5 8}$ & \\
\hline \multicolumn{4}{|c|}{ Own value } & 5,905 & \multirow{3}{*}{$\begin{array}{c}\text { KMO }=\mathbf{0 , 8 5 5} \\
\mathbf{P}=\mathbf{0 . 0 0 0} \\
\mathbf{N}=\mathbf{1 2 0}\end{array}$} \\
\hline \multicolumn{4}{|c|}{ Bartlett test: Significant } & Varimax & \\
\hline \multicolumn{4}{|c|}{ Variance explained in $\%$} & $65,60 \%$ & \\
\hline
\end{tabular}

Table 5. Results purification of the measurement scale of the variable "Top Management Support "

\begin{tabular}{|c|c|c|c|c|c|}
\hline \multirow{2}{*}{ Variable } & \multirow{2}{*}{$\begin{array}{l}\text { List of } \\
\text { items }\end{array}$} & \multirow{2}{*}{$\begin{array}{l}\text { Number } \\
\text { of items }\end{array}$} & \multirow{2}{*}{$\begin{array}{l}\text { Quality of } \\
\text { representation }\end{array}$} & $\begin{array}{c}\text { Factor } \\
\text { contribution }\end{array}$ & \multirow{2}{*}{ Reliability } \\
\hline & & & & $\begin{array}{c}\text { Component } \\
1\end{array}$ & \\
\hline \multirow{4}{*}{$\begin{array}{c}\text { Top } \\
\text { Management } \\
\text { Support }\end{array}$} & TMS1 & \multirow{4}{*}{4} & 0,799 & 0,894 & \multirow{4}{*}{0,923} \\
\hline & TMS2 & & $\mathbf{0 , 8 1 1}$ & 0,901 & \\
\hline & TMS3 & & 0,828 & 0,910 & \\
\hline & TMS4 & & $\mathbf{0 , 8 1 7}$ & 0,904 & \\
\hline \multicolumn{4}{|c|}{ Own value } & 3,255 & \multirow{3}{*}{$\begin{array}{c}\text { KMO }=0,854 \\
P=0.000 \\
N=120\end{array}$} \\
\hline \multicolumn{4}{|c|}{ Bartlett test: Significant } & Varimax & \\
\hline \multicolumn{4}{|c|}{ Variance explained in $\%$} & $81,37 \%$ & \\
\hline
\end{tabular}


Table 6. Results purification of the scale of measurement of the variable "Business Performance "

\begin{tabular}{|c|c|c|c|c|c|}
\hline \multirow{2}{*}{ Variable } & \multirow{2}{*}{$\begin{array}{l}\text { List of } \\
\text { items }\end{array}$} & \multirow{2}{*}{$\begin{array}{l}\text { Number } \\
\text { of items }\end{array}$} & \multirow{2}{*}{$\begin{array}{c}\text { Quality of } \\
\text { representation }\end{array}$} & $\begin{array}{c}\text { Factor } \\
\text { contribution }\end{array}$ & \multirow{2}{*}{ Reliability } \\
\hline & & & & $\begin{array}{c}\text { Component } \\
1\end{array}$ & \\
\hline \multirow{6}{*}{$\begin{array}{c}\text { Business } \\
\text { performance }\end{array}$} & CP1 & \multirow{6}{*}{6} & 0,762 & $\mathbf{0 , 8 7 3}$ & \multirow{6}{*}{0,953} \\
\hline & CP2 & & $\mathbf{0 , 8 0 2}$ & 0,895 & \\
\hline & CP3 & & 0,783 & $\mathbf{0 , 8 8 5}$ & \\
\hline & CP4 & & $\mathbf{0 , 8 1 0}$ & 0,900 & \\
\hline & CP5 & & 0,822 & 0,907 & \\
\hline & CP6 & & $\mathbf{0 , 8 8 5}$ & 0,941 & \\
\hline \multicolumn{4}{|c|}{ Own value } & 4,864 & \multirow{3}{*}{$\begin{array}{c}\text { KMO }=0,869 \\
P=0.000 \\
N=120\end{array}$} \\
\hline \multicolumn{4}{|c|}{ Bartlett test: Significant } & Varimax & \\
\hline \multicolumn{4}{|c|}{ Variance explained in \% } & $81,06 \%$ & \\
\hline
\end{tabular}

An exploratory factor analysis using SPSS 25.0 was performed on the three variables in the model. Varimax rotation was used to determine the number of component factors (Manning \& Munro, 2007). Items with communities less than 0.4 and items with factor loadings greater than 0.3 on more than one component were removed from the measurement scale (Roussel, 2005).

The final results of the exploratory factor analysis provided in the three tables show a single factor structure for each variable.

In terms of quality of representation, the results indicate that all items for the three variables have a commonality greater than 0.5 .

These results indicate that all scales are unidimensional, meaning that all items are assumed to measure a single underlying construct (Hair et al., 2006). In addition, all Cronbach's alpha values are greater than 0.9 and meet the recommendation of Roussel (2005).

Finally, we can distinguish that all the items of the three variables meet the scientific standards in management science.

\section{Confirmatory Exploratory Analysis: Structural Equation Method}

Our following conceptual model is composed of three variables, and its relationships have been declined in the form of hypotheses. Here, we will try to validate them in this section. 


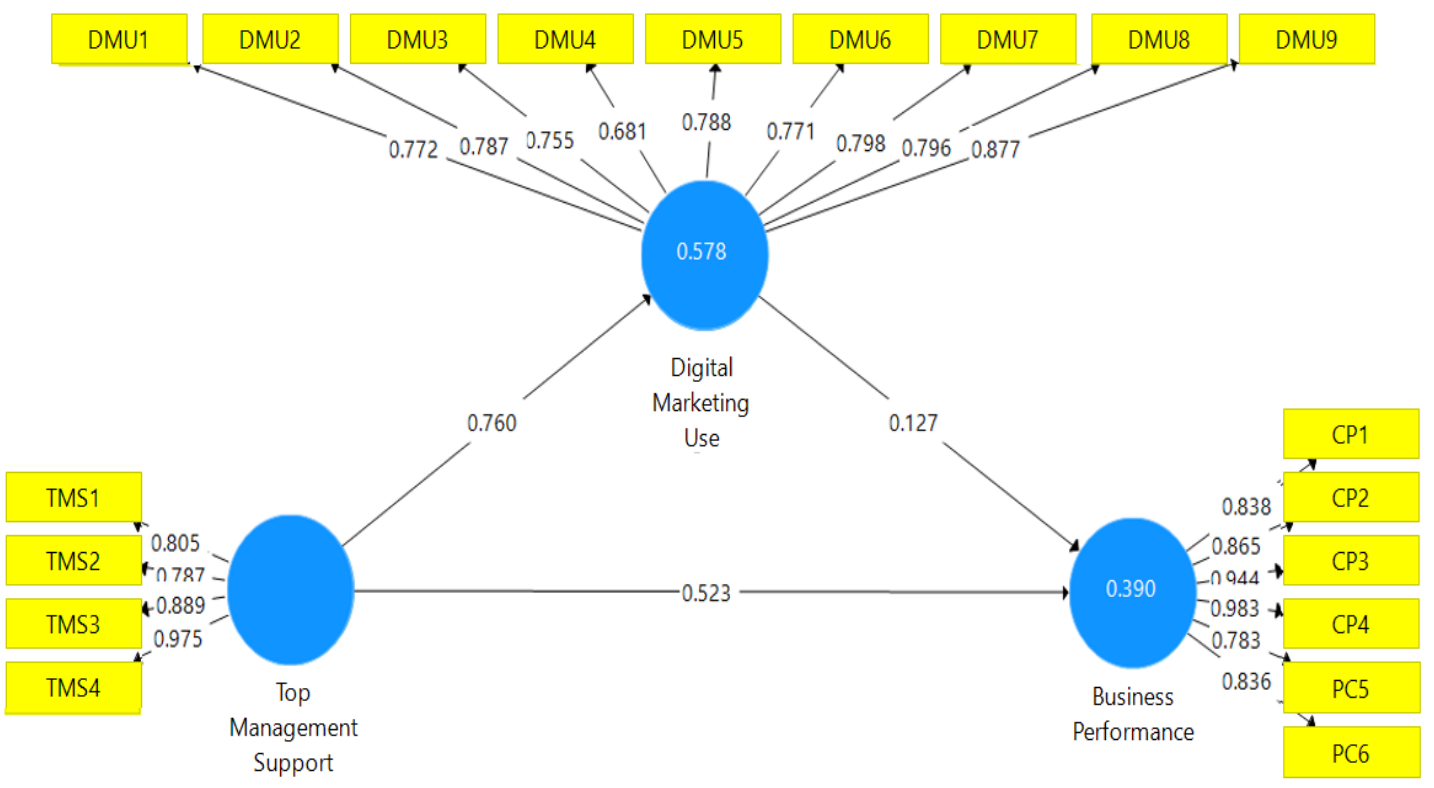

Figure 3. The adjusted structural model (using Smart PLS Software)

There are four elements to the validity of the measurement model: cronbach's alpha, Rho_A, Composite reliability, and AVE.

According to the Table 7, we can see that all the variables met the accepted value at the level of cronbach's alpha, rho_A, composite reliability, and AVE and exceeded 0.6 and met the accepted value or the recommendations of the authors (Hair et al., 2014; Tenenhaus, 1999; Michel Tenenhaus et al., 2005).

Convergent validity is affirmed when each construction has an AVE's greater than 0.5 (Hair et al., 2014; Tenenhaus, 1999; Michel Tenenhaus et al., 2004).

The results provided in Table 7 show that the AVE's are 0.6 higher. This means that convergent validity is demonstrated.

Table 7. Validity of the measurement model

\begin{tabular}{|c|c|c|c|c|}
\cline { 2 - 5 } & $\begin{array}{c}\text { Cronbach's } \\
\text { Alpha }\end{array}$ & rho_A & $\begin{array}{c}\text { Composite } \\
\text { Reliability }\end{array}$ & $\begin{array}{c}\text { Average } \\
\text { Variance } \\
\text { Extracted } \\
\text { (AVE) }\end{array}$ \\
\hline Business Performance & $\mathbf{0 . 9 5 3}$ & $\mathbf{0 . 9 5 6}$ & $\mathbf{0 . 9 5 2}$ & $\mathbf{0 . 7 7 0}$ \\
\hline $\begin{array}{c}\text { Top Management } \\
\text { Support }\end{array}$ & $\mathbf{0 . 9 2 4}$ & $\mathbf{0 . 9 3 1}$ & $\mathbf{0 . 9 2 3}$ & $\mathbf{0 . 7 5 2}$ \\
\hline Digital Marketing Use & $\mathbf{0 . 9 3 4}$ & $\mathbf{0 . 9 3 6}$ & $\mathbf{0 . 9 3 4}$ & $\mathbf{0 . 6 1 2}$ \\
\hline
\end{tabular}




\subsection{Multicolinearity of the Variables in our Research}

Discriminant validity is asserted when each element has an element loading greater than 0.7 on its respective construction (Hair et al., 2011), especially when the square root of all constructions is greater than all other extracted mean variances (AVE) cross-correlations, and no element is highly loaded on another construction.

The results also show that the values on the diagonal are greater than all the values on the lower part of the diagonal, which asserts discriminant validity.

It is also clear that the elements are strongly correlated with their corresponding construction and weakly correlated with other constructions. This confirms the discriminant validity of the measurement scales (Tables 8 and 9).

Table 8. Represents the result of the regression (Discrimiant Validity)

\begin{tabular}{|c|c|c|c|}
\cline { 2 - 4 } \multicolumn{1}{c|}{} & $\begin{array}{c}\text { Business } \\
\text { Performance }\end{array}$ & $\begin{array}{c}\text { Top } \\
\text { Management } \\
\text { Support }\end{array}$ & $\begin{array}{c}\text { Digital } \\
\text { Marketing Use }\end{array}$ \\
\hline Business Performance & $\mathbf{0 . 8 7 7}$ & & \\
\hline Top Management Support & 0.619 & $\mathbf{0 . 8 6 7}$ & \\
\hline Digital Marketing Use & 0.524 & 0.760 & $\mathbf{0 . 7 8 2}$ \\
\hline
\end{tabular}

The presence of strong correlations above a threshold of 0.70 indicates the existence of multicollinearities that may affect the regression results (Jolibert \& Jourdan, 2006).

Table 9. Correlation matrix and the square root of the AVE

\begin{tabular}{|c|c|c|c|}
\hline & $\begin{array}{c}\text { Business } \\
\text { Performance }\end{array}$ & $\begin{array}{c}\text { Top } \\
\text { Management } \\
\text { Support }\end{array}$ & $\begin{array}{c}\text { Digital } \\
\text { Marketing Use }\end{array}$ \\
\hline CP1 & 0.838 & & \\
\hline CP2 & 0.865 & & \\
\hline CP3 & 0.944 & & \\
\hline CP4 & 0.983 & & \\
\hline CP5 & 0.783 & & \\
\hline CP6 & 0.836 & & \\
\hline MTS1 & & 0.805 & \\
\hline MTS2 & & 0.787 & \\
\hline MTS3 & & 0.889 & \\
\hline MTS4 & & 0.975 & \\
\hline DMU1 & & & 0.772 \\
\hline
\end{tabular}




\begin{tabular}{|l|l|l|}
\hline DMU2 & \multirow{5}{*}{} & 0.787 \\
\hline DMU3 & \multirow{5}{*}{} & 0.755 \\
\hline DMU4 & & 0.681 \\
\hline DMU5 & & 0.788 \\
\hline DMU6 & & 0.771 \\
\hline DMU7 & & 0.798 \\
\hline DMU8 & & 0.796 \\
\hline DMU9 & & 0.877 \\
\hline
\end{tabular}

The values of the square root of the AVE shown diagonally in Table 9 are acceptable. Thus, we found that all reliability coefficients are satisfactory and are greater than and equal to 0.6.

The principle of the independence of the explanatory variables must be respected (Evrard et al., 2003). We present the variance inflation factor (VIF for Variance Inflation Factor), which must be less than 3 (Carricano \& Poujol, 2008) or 4 (Evrard et al., 2003).

Based on the results, we found that the VIF of only two items in the "Business Performance" variable were 4 higher than CP5 and CP6, and did not meet the recommendations of the authors mentioned above.

In this case, we decided to remove the two items from the "Business Performance" variable, in order to have the only items that met the recommendations of the authors mentioned above.

Table 10. Threshold of the VIF index of items

\begin{tabular}{|c|c|}
\cline { 2 - 2 } \multicolumn{1}{c|}{ CP1 } & VIF \\
\hline CP2 & 3.053 \\
\hline CP3 & 3.528 \\
\hline CP4 & 4.000 \\
\hline MTS1 & 3.874 \\
\hline MTS2 & 2.950 \\
\hline MTS3 & 3.077 \\
\hline MTS4 & 3.353 \\
\hline DMU1 & 3.211 \\
\hline DMU2 & 2.457 \\
\hline DMU3 & 3.252 \\
\hline DMU4 & 3.168 \\
\hline DMU5 & 3.617 \\
\hline DMU6 & 3.199 \\
\hline DMU7 & 3.204 \\
\hline DMU8 & 2.707 \\
\hline DMU9 & 3.198 \\
\hline
\end{tabular}


We noted that the indices mentioned above meet the thresholds recommended by the authors (Carricano \& Poujol, 2008; Evrard et al., 2003).

\subsection{Predictive Validity of the Model}

\subsubsection{Tests of the Causal Relations of the Conceptual Model}

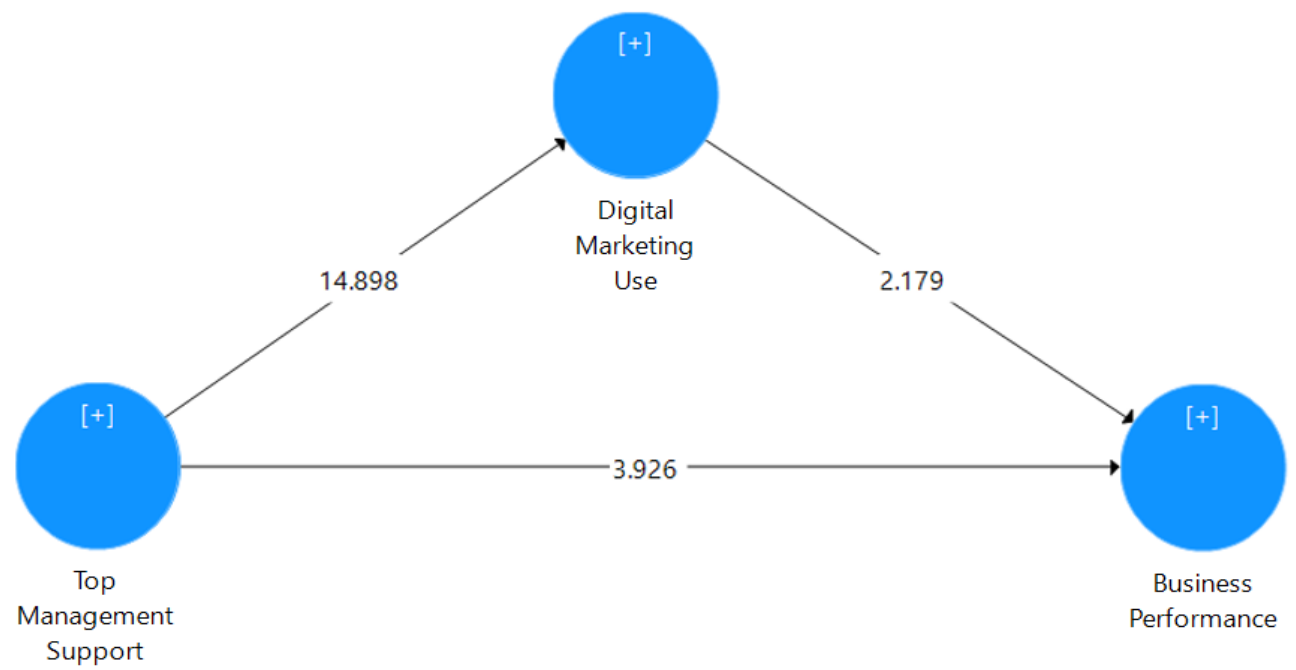

Figure 4. The fitted structural model (Bootstrap)

At the level of the structural model, we evaluated the R2 coefficient of determination and, according to our analysis, we found that our R2 is moderate.

Table 11. Validity of the measurement model (R.Square)

\begin{tabular}{|l|c|}
\cline { 2 - 2 } \multicolumn{1}{c|}{ R Square } \\
\hline Business Performance & 0.427 \\
\hline Digital Marketing Use & 0.577 \\
\hline
\end{tabular}

Chin (1998) suggests that R-squared values of $0.67,0.33$, and 0.19 in PLS-SEM can be considered substantial, moderate, and low, respectively.

Chin (1998) suggested that R2 values above 0.67 were considered high, values between 0.33 and 0.67 were moderate, values between 0.19 and 0.33 were low, and R2 values below 0.19 were unacceptable in PLS-MES.

For R2 in our model is equal to 0.427 , which shows that our model is moderate.

The size effect is presented as follows: 
Table 12. $F^{2}$ value of exogenous latent variables

\begin{tabular}{|c|c|c|c|c|}
\cline { 2 - 5 } \multicolumn{1}{c|}{} & $\begin{array}{c}\text { Business } \\
\text { Performance }\end{array}$ & $\begin{array}{c}\text { Top } \\
\text { Management } \\
\text { Support }\end{array}$ & $\begin{array}{c}\text { Digital } \\
\text { Marketing } \\
\text { Use }\end{array}$ & Result \\
\hline $\begin{array}{c}\text { Top Management } \\
\text { Support }\end{array}$ & $\mathbf{0 . 1 7 3}$ & & 1.367 & Significant \\
\hline Digital Marketing Use & $\mathbf{0 . 0 3 0}$ & & $\begin{array}{c}\text { Moderate } \\
\text { effect }\end{array}$ \\
\hline
\end{tabular}

$\mathrm{F}^{2}$ values were found to be greater than 0 , illustrating that each predictor takes part of the dependent variable. However, the size effects vary between low and medium and is significant for the variable "Use of digital marketing" and "Top management support", respectively.

The quality of the size effect for the two variables "Digital marketing use" and "Top management support" is respected according to the recommendations of Croutsche (2009), Henseler et al. (2009), and Tenenhaus (1999).

The calculation of model quality is as follows:

$$
G o F=\sqrt{\left(\overline{R^{2}} \times \overline{A V E)}\right.}
$$

According to the criteria of Wetzels, Odekerken-Schröder, and Van Oppen (2009), we found that the value of the GoF is equal to $\mathbf{0 . 5 9 8}$, and we can conclude that the GoF model of this study is high and important enough to consider a sufficient validity of the PLS model.

Table 13. Results of Structural Model Estimates on the Overall Sample

\begin{tabular}{|c|c|c|c|c|c|c|}
\hline \multirow[b]{2}{*}{ Hypothesis } & \multicolumn{5}{|c|}{ Path coefficients (Mean, STDEV, T-Values) } & \multirow[b]{2}{*}{ Description } \\
\hline & $\begin{array}{l}\text { Original } \\
\text { Sample } \\
\text { (O) }\end{array}$ & $\begin{array}{c}\text { Sample } \\
\text { Mean } \\
\text { (M) }\end{array}$ & $\begin{array}{l}\text { Standard } \\
\text { Deviation } \\
\text { (STDEV) }\end{array}$ & $\begin{array}{c}\text { T Statistics } \\
(|\mathrm{O} / \mathrm{STDEV}|)\end{array}$ & $\begin{array}{c}\mathbf{P} \\
\text { Values }\end{array}$ & \\
\hline $\begin{array}{c}\text { Top Management } \\
\text { Support -> Business } \\
\text { Performance } \\
\end{array}$ & 0.435 & 0.447 & 0.111 & 3.926 & 0.000 & Accepted \\
\hline $\begin{array}{c}\text { Top Management } \\
\text { Support -> Digital } \\
\text { Marketing Use }\end{array}$ & 0.709 & 0.708 & 0.048 & 14.898 & 0.000 & Accepted \\
\hline $\begin{array}{c}\text { Digital Marketing Use } \\
\text {-> Business } \\
\text { Performance }\end{array}$ & 0.225 & 0.218 & 0.103 & 2.179 & $\mathbf{0 . 0 3 0}$ & Accepted* \\
\hline
\end{tabular}

Significant to $\mathrm{P}^{*}<0.05, \mathrm{~T}>1.90$

The main empirical results of the research for all data show that top management support has a significant positive effect on business performance (coeff. $=0.435 ; \mathrm{p}<0.01$ ) and that top management support has a significant positive effect on the digital marketing use (coeff. $=0.709 ; \mathrm{p}<$ 
0.01). In addition, we found that the digital marketing use has a positive effect on business performance (coeff. $=0.225 ; \mathrm{p}>0.01$ ).

\section{Research Results and Discussion}

The analysis of the empirical study data yielded a very important result. This result concludes three validated hypotheses.

Table 14. Research Hypothesis Results

\begin{tabular}{|c|c|c|c|}
\hline Hypothesis & $\begin{array}{c}\text { Statement of the } \\
\text { hypothesis }\end{array}$ & Result & \multicolumn{1}{c|}{$\begin{array}{c}\text { Results similar to the } \\
\text { literature }\end{array}$} \\
\hline \multirow{3}{*}{$\mathbf{H 1}$} & $\begin{array}{c}\text { Top management support } \\
\text { has a positive impact on } \\
\text { business performance. }\end{array}$ & Validated & $\begin{array}{l}\text { (Ferhane, 2019; Sheikh et al., } \\
2018 ; \text { Germann et al., 2013; } \\
\text { Brentani \& Kleinschmidt, } \\
\text { 2004). }\end{array}$ \\
\hline \multirow{3}{*}{$\mathbf{H 2}$} & $\begin{array}{c}\text { Top management support } \\
\text { has a positive impact on } \\
\text { the digital marketing use. }\end{array}$ & Validated & $\begin{array}{l}\text { (Ferhane, 2019; Trainor et al., } \\
\text { 2011; Brodie et al., 2007; } \\
\text { Brodie et al., 2007; Brentani } \\
\text { \& Kleinschmidt, 2004). }\end{array}$ \\
& $\begin{array}{c}\text { The digital marketing use } \\
\text { has a positive impact on } \\
\text { business performance. }\end{array}$ & Validated & $\begin{array}{l}\text { Ferhane, 2019; Sheikh et al., } \\
\text { 2018; Strauss \& Frost, 2014; } \\
\text { Day, 2013; Trainor et al., } \\
2011 ; \text { Adam et al., 2009; } \\
\text { Brodie et al., 2007; Simpson, } \\
\text { 2007) }\end{array}$ \\
\hline
\end{tabular}

In summary, there is no much difference between the number of items before and after the analysis of the structural equations, with the exception of the number of items of the "Business Performance" variable, which decreased by two items at the purification level in order to improve the structure of the model.

Table 15. Summary of analysis of structural equations

\begin{tabular}{|c|c|c|c|}
\hline Variables & $\begin{array}{c}\text { Number of } \\
\text { items before } \\
\text { the analysis } \\
\text { of structural } \\
\text { equations }\end{array}$ & $\begin{array}{c}\text { Number of } \\
\text { items after } \\
\text { analyzing } \\
\text { structural } \\
\text { equations }\end{array}$ & $\begin{array}{c}\text { Cronbach's } \\
\text { alpha }\end{array}$ \\
\hline Digital Marketing Use & 9 & 9 & $\mathbf{0 . 9 3 4}$ \\
\hline Top Management Support & 4 & 4 & $\mathbf{0 . 9 2 4}$ \\
\hline Business performance & 6 & 4 & $\mathbf{0 . 9 2 5}$ \\
\hline
\end{tabular}




\section{Conclusion}

Today, the web has become the main place where information is disseminated, and it is indeed Internet users who publish the vast majority of this information. Most Moroccan companies have relatively well assimilated the challenges of a presence on the new media, but are not yet able to exploit digital technology at its true value.

In today's world, companies are exposed to increasingly tough and permanent competition and are driven to streamline, optimize, and automate their processes by relying on digital technology. This would enable them to gain in productivity and profitability differentials and to defend their acquired positions within the competition (Mebarki, 2013, p. 114). Today, no company can depart from the use of digital technology at the risk of compromising its performance.

The objective of this research was to explain the degree of digital adoption in Moroccan companies by questioning its impact on business performance.

Like all scientific research in Management, our work has some methodological limitations. For example, the subject has not captured details about the use of digital marketing across different industries or sectors. Different industries experience a set of dynamics and challenges that can change the impact of digital marketing on different companies.

We also focused on a few studies that did not highlight the risks and dangers that digital marketing poses to Moroccan businesses. Information on the risks, challenges, and obstacles to implementing digital marketing has therefore not been highlighted despite its importance. Future research on this topic should expand research on the risks and challenges presented by digital media to help companies overcome the unique challenges that compromise their ability to succeed in digital marketing.

In conclusion, this work allowed us to answer our research question by explaining the practices of digital marketing and by studying the impact of digital marketing on the business performance of companies in the northern region of Morocco. It also helps to highlight the importance of digital marketing in improving business performance. 


\section{References:}

Adam, S., Vocino, A., \& Bednall, D. (2009). The world wide web in modern marketing's contribution to organisational performance. Marketing Intelligence et Planning, 27(1), pp. 7- 24.

Alain Jolibert \& Philippe Jourdan (2006). Marketing Reseach : méthodes de recherche et d'études en marketing. Dunod, Paris.

Aurier, P., Evrard, Y. \& N'Goala, G. (2000). Valeur de consommation et valeur globale : Une application au cas de la consommation cinématographique, Actes du l6ème Congrès International de l'Association Française du Marketing, Montréal, AFM, 152- 162.

Besson, M. (2016). Entreprise du futur, les enjeux de la transformation numérique, Livre blanc, Paris : Institut Mines-Télécom.

Brentani, U., \& Kleinschmidt. E. J. (2004). Corporate Culture and Commitment: Impact on Performance of International New Product Development Programs. Journal of Product Innovation Management (21), pp. 309-333.

Bressolles, G. (2016). Le marketing digital, Dunod ,2ème édition, Paris, $127 \mathrm{p}$.

Brodie, et al. (2007). Is e-marketing coming of age? an examination of the penetration of emarketing and firm performance. Journal of Interactive Marketing.

Chin, W. W., Peterson, R. A., \& Brown, S. P. (2008). Structural equation modeling in marketing: some practical reminders. Journal of Marketing Theory and Practice, 16(4), 287-298.

Churchill, G-A. (1979). A paradigm for developing better measures of marketing constructs, Journal of Marketing Research, vol.16:1, 6473.

Daellenbach, U. S., McCarthy, A. M., \& Schoenecker, T. S. (2002, Decembre 17). Commitment to Innovation: The Impact of Top Management Team Characteristics. $R \& D$ Management.

Day, G., \& Bens, K. (2005). Capitalizing on the Internet Opportunity. Journal of Business \& Industrial Marketing.

Deloitte (2016). Economie numérique: Le digital, une opportunité pour les $P M E$

françaises.

https://www2.deloitte.com/content/dam/Deloitte/fr/Documents/strate gy/deloitte_digitalopportunite-pme-francaises_jan2017.pdf

Dudézert, A. (2018). La transformation digitale des entreprises. La Découverte, " Repères », 2018, 128 pages. ISBN: 9782348036019. URL:https://www.cairn.info/la-transformationdigitaledes-entreprises-9782348036019.htm

Ferhane (2019). L'impact du marketing digital sur la performance des entreprises: Cas d'un échantillon d'entreprises Algériennes, thèse de 
doctorant en sciences économiques, Universite djillali liabes de sidi belabbes.

Flores (2012). Mesurer l'efficacité du marketing digital, Dunod, Paris, 2012, P 4.

Hair, J. F., Black, W. C., Babin, B. J., Anderson, R. E., \& Tatham, R. L. (2006). Multivariate data analysis (Vol. 6). Upper Saddle River, NJ: Pearson Prentice Hall.

Harvard Business Review (2015). Driving digital transformation : new skills for leaders, new role for the CIO. Harvard Business School Publishing.

Kenmogne, A, Djipwo, F. P., \& Feudjo, J. R. (2018). Influence de l'innovation sur la satisfaction et la fidélité de la clientèle dans le secteur de la téléphonie mobile au Cameroun, International Journal of Business et Economic Strategy, 10, 35-45

Manning, M.L. \& Munro, D. (2007). The survey researcher's SPSS cookbook, 2nd edn, Pearson Education Australia, Frenchs Forest, NSW.

Manu Carricano \& Fanny Poujol (2008). Analyse de données avec SPSS, Edition Pearson.

Marchesnay, M. (1991), Economie d'entreprise. Ed Eyrolles.

Mebarki, N. (2015), TIC et performance d'entreprise : Étude d'impact - cas de quelques entreprises Algeriennes, Vol.104, African Journals Online.

Ouattara, P. (2007). Diagnostic financier et performance d'une entreprise en Côte d'Ivoire». MBA Finance d'entreprise, Ecole Supérieure de Gestion de Paris : Blog Axlane: accélérateur de croissance.

Plauchu, V. \& Tairou, A. (2008). Méthodologie du diagnostic de l'entreprise. L'Harmattan, Paris, France, 298p.

Roussel (2005). Méthodes de développement d'échelles pour questionnaires d'enquête. Dans Management des ressources humaines (2005), pages 245 à 276 .

Sheikh, et al. (2018, September). Is e-marketing a source of sustainable business performance? Predicting the role of top management support with various interaction factors. Cogent Business et Management.

Simpson, P. (2007). Direct marketing: Options for the future. Journal of Direct, Data and Digital Marketing Practice.

Strauss, J., \& Frost, R. (2014). E-Marketing. International Edition technology: Stevens institute of technology.

Tenenhaus, M. (1999). L'approche PLS. Revue de Statistique Appliquée, 47 (2), 5-40. 
Trainor, K., Rapp, A., Skinner Beitelspacher, L., \& Schillewaert, N. (2011). Integrating information technology and marketing: An examination of the drivers and outcomes of eMarketing capability. Industrial Marketing Management.

Waldman, D-A. (1994). La gestion de la performance et la qualité totale, Gestion, Vol.19, n³, pp. 39-47. 